\title{
THE CALCIUM METABOLISM OF PREMATURE INFANTS *
}

\author{
BENGT HAMILTON \\ STOCKHOLM, SWEDEN
}

The calcium metabolism of premature infants has hitherto not been studied systematically. Such a study is, however, well justified by the fact that these infants are more liable to. acquire rachitis than full-term babies. It is also a common experience that bone symptoms appear in the prematurely born at an early age, and that the condition more often takes a grave course than in other infants. It has been assumed that this tendency is caused by the absence of a congenital store of calcium, supposed to be present in full-term new-borns. About 85 per cent. of the body's calcium at birth is stored during the last two or three months of fetal life. ${ }^{1}$ We do not know, however whether the large amount of calcium, thus retained, may in postnatal life really play the rôle of a depôt, the contents of which are available for the processes of growth. Be this as it may, a premature birth means that the body is exposed to postnatal life containing a proportionately very small amount of calcium. It has been surmised that this fact may be at least partially responsible for the prevalence of rachitis among the prematures.

If the calcium stored in the last months of fetal life, really is essential to the normal postnatal growth of the body, the premature birth would, it seems, lead to a state of calcium starvation. According to the present state of knowledge, however, rachitis and calcium starvation are not identical conditions. It might be possible that the assumed calcium starvation of the prematures would in some way make them more susceptible to rachitis. But there is also another possibility, namely, that some of the so-called rachitic symptoms of the prematures have nothing to do with rachitis, but are symptoms of simple osteoporosis.

One peculiarity of rachitis in prematures is the very early appearance of craniotabes. This symptom, rarely seen in full-term infants before the beginning of the fourth month, very often appears in prematures as early as the second month of life. (The craniotabes in prematures must not be confused with the general elastic flexibility of the flat bones of the skull in these infants; nor, of course, with con-

\footnotetext{
*From the "Sachs" Baby Hospital.

* Read in part before the First Scandinavian Pediatric Congress, Copenhagen, August, 1919.

1. Schloss: Die Pathogenese und Aetiologie der Rachitis sowie die Grundlagen ihrer Therapie, Ergebn. d. inn. Med. u. Kinderh. 15:55, 1917.
} 
genital bone defects). This early craniotabes of the prematures often develops to an extent rarely seen in infants born at full term. It is noteworthy that this excessive softening of the flat bones of the skull is often found in breastfed prematures in the best hygienic conditions, spared from infections and gaining rapidly in weight. The general condition of these infants; their often remarkable vitality, makes one doubt whether they are suffering from a rather severe disease; clinical observation as well as theoretical speculation therefore justifies the assumption of a nonrachitic origin of their symptoms in many cases.

The predisposition of prematures to acquire rachitis, however, can hardly be denied altogether. Among the cases of malignant rachitis in older infants, the cases with severe deformities of thorax and extremities, with general slackness of the muscles, there is a large percentage of prematures according to the experience gathered at this hospital.

TABle 1.-Summary of the Main Results of Previous Works on Calcium Metabolism of Breast-Fed Infants

\begin{tabular}{|c|c|c|c|c|c|c|}
\hline \multirow{2}{*}{ Author } & \multirow{2}{*}{$\begin{array}{c}\text { Age } \\
\text { in } \\
\text { Mos. }\end{array}$} & \multirow{2}{*}{ Weight } & \multicolumn{4}{|c|}{ Caleium Oxid } \\
\hline & & & $\begin{array}{l}\text { Total } \\
\text { Intake }\end{array}$ & $\begin{array}{l}\text { Intake } \\
\text { per Kg. }\end{array}$ & $\begin{array}{c}\text { Total } \\
\text { Retention }\end{array}$ & $\begin{array}{l}\text { Retention } \\
\text { per } \mathbf{K g} \text {., }\end{array}$ \\
\hline 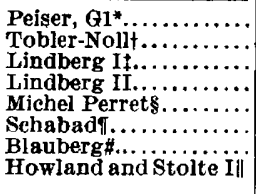 & $\begin{array}{l}2 \\
2.5 \\
2.5 \\
2.5 \\
3 \\
4 \\
5 \\
5\end{array}$ & $\begin{array}{c}3,720 \\
4,000 \\
4,285 \\
4,370 \\
4,725 \\
7,700 \\
6,740 \\
\text { About } \\
4,250\end{array}$ & $\begin{array}{l}0.279 \\
0.2390 \\
0.2572 \\
0.2615 \\
0.377 \\
0.3636 \\
0.272 \\
0.3337\end{array}$ & $\begin{array}{l}0.075 \\
0.0598 \\
0.0600 \\
0.0598 \\
0.080 \\
0.0472 \\
0.0404 \\
0.0785\end{array}$ & $\begin{array}{l}0.048 \\
0.0533 \\
0.0562 \\
0.0639 \\
0.149 \\
0.1815 \\
0.1754 \\
0.1053\end{array}$ & $\begin{array}{l}0.013 \\
0.0133 \\
0.0131 \\
0.0146 \\
0.032 \\
0.0236 \\
0.0260 \\
0.0248\end{array}$ \\
\hline Howland and Stolte II & 6 & $\begin{array}{c}4,2 b 0 \\
\Lambda \text { bout } \\
4,400\end{array}$ & 0.3307 & 0.0752 & 0.1107 & 0.0252 \\
\hline
\end{tabular}

* Peiser: Beiträge zur Kenntnis des stoflweehsels, besonders der Mineralien im Säugling salter, Juhrb, f. Kinderh, $\mathbf{8 1}: 437,1915$.

t Tobler and Noll: Zur kenntnis des Mineralstoffwechsels beim gesunden Brustkind, Monatschr. f. Kinderh. $9: 210,1910$

† Ifingberg: Ueber den Stoffwechsel des gesunden, ratürlicl ernährten Säuglings und dessen Beeinflussung durch Frauenmilchfett, Ztschr, f. Kinderh. 16 :90, 1917.

\& Miehel and Perret: Etude des échanges nutritifs azotés et mineraux chez un nourrison, Bull. Soc. d'obstét. de Par. 1899.

I Schabad: Zur Bedeutung des Kalkes in der Pathologie der Rachitis, Arch. f. Kinderh. $52: 47,53: 380,54: 83,1910$.

\# Blauberg: Ueber den Mineralstofíwechscl beim natürlicli ernährten Säugling, Ztschr. f. Biol. $40: 36$, 1900 .

Howland and Stolte: Die Bedeutung von liweisszulagen beim Säugling, Jahrb. f. kinterh. $88: 85,1918$.

The proportionately small amount of calcium in the body of the new-born premature may, as mentioned above, possibly lead to a state of calcium starvation in the course of postnatal growth. There are, however, in the postnatal growth of the premature often certain characteristic features which also might unfavorably influence the calcium metabolism. Although the difference in corporal development between the premature and the full term new-born may be very great, 
there is in the healthy premature, when properly nourished and cared for, a great tendency to make good this difference. It is not unusual for such an infant to double its weight in three months and triple it in six months. The question now arises, whether the tissues formed by this rapid growth are of the same composition as in the more slowly growing bodies of normal infants. We know how the tissues formed in a rapid recovery from an acute or chronic nutritional disturbance; contain much water and are poor in salts. It may well be supposed that the same would be the case in the rapidly growing bodies of prematures. If this should be so, their bodies, already containing but a small amount of calcium at birth, would soon be really impoverished in respect to this substance.

The work of Klotz has been excluded, first because the infant practically did not gain in weight, and second because the calcium intake was abnormally low. One of Peiser's infants (infant Band) has also been excluded. This infant developed symptoms of syphilis some time after its metabolism had been studied and cannot, therefore, be considered a normal infant.

A study was made of infants born from four to ten weeks before full term. The cause of the premature birth was advanced pulmonary tuberculosis of the mother in three cases, nephritis and eclampsia in one case. In the cases of tuberculosis, the infants were separated from the mothers immediately after delivery. Symptoms of syphilis and tuberculosis were absent in all cases during the time of observation. The Wassermann test was negative. The infants were nourished from birth exclusively with breast milk given in bottles; they gained rapidly in weight during the months in which the experiments were carried out. A slight tendency to subnormal temperature was easily overcome. The stools were at times loose and frequent, both during the experiments and in the intervals. Such stools are often seen in normal babies fed with breast milk, and are nowadays not considered pathologic when, as in these cases, the infants are in all respects healthy, gaining in weight and showing a normal temperature.

The method used for collecting the stools and the urine was that described by Bendix-Finkelstein, slightly modified. Calcium was determined according to McCrudden.

The iron metabolism. of these same infants was studied by Lichtenstein as a sequel to hematologic studies made on prematures. ${ }^{2}$ The result of this study has not yet been published.

2. Lichtenstein: Hämatologiska studier å för tidigt födda barn, Svenska Läk.-Sällsk. Handl. 43:1533, 1917 (abstr. in Jahrb. f. Kinderh. 88:387, 1918. 


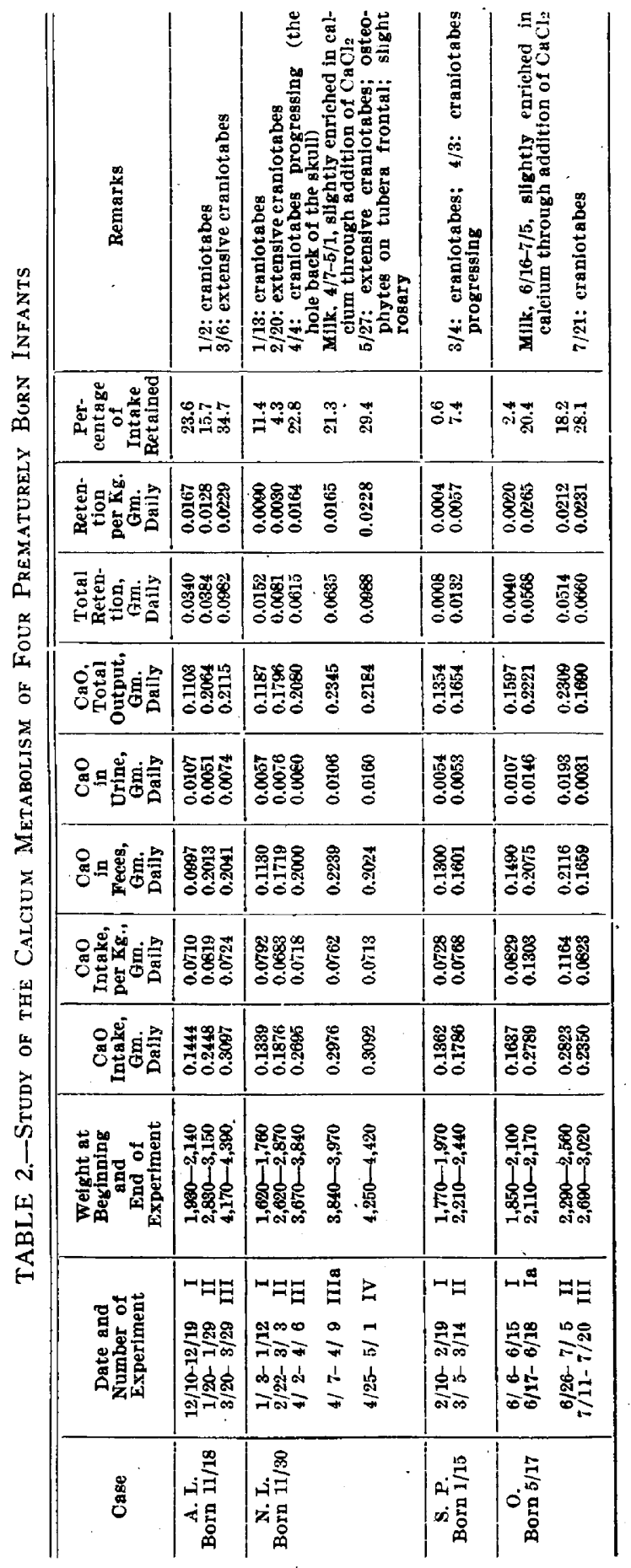




\section{REPORT OF CASES}

CASE 1.-A. L., horn Nov. 18, 1918, four weeks before full term, with a birth weight of $1,930 \mathrm{gm}$. Admitted to the "Sachs" Baby Hospital November 27.

The calcium metabolism of this infant was studied in the second, third and fifth month (ten day periods). The calcium retentions found per kilogram of body weight were of the same magnitude as those found by other investigators in full term infants. Craniotabes appeared shortly after the end of the first period and progressed rapidly in the following months.

CASE 2.-N. L., born Nov. 30, 1918, from eight to ten weeks before full term. Birth weight, $1,550 \mathrm{gm}$. Admitted December 13.

The calcium retentions found in the second and third months (two ten day periods) were very low. Craniotabes appeared in the second month and progressed rapidly, until in the fourth month the whole back of the skull was softened. Somewhat later there also developed osteophytes on the frontal bones and rosary. At this time a five day period showed a tolerable calcium retention. Calcium chlorid was now added to the milk (about 0.03 gm. daily); the retention remained the same (period III a, three days). The administration of calcium chlorid was continued, and two weeks afterward the retention was decidedly better (period·IV, seven days), whether because of the artificially increased intake it is impossible to decide.

This infant spent thirty-five days out of 124 on the metabolism frame. The calcium retention was never found to be negative, although pronounced pathologic bone symptoms appeared and progressed during this time.

CASE 3.-S. P., born Jan. 15, 1919, from six to eight weeks before full term with a birth weight of $1,600 \mathrm{gm}$. Admitted January 17 .

The calcium metabolism was studied in the first and second month of life (ten day periods). The retentions were very low. Craniotabes appeared in the second month.

Case 4.-O. - born May 17, 1919, one month before full term. Birth weight $1,670 \mathrm{gm}$. Admitted May 24.

The first experiment with this infant was made when it was 3 weeks old (a ten day period). The calcium retention was found to be very low $(0.0020$ gm. per kilogram). When this period was finished, calcium chlorid was added to the milk (about $0.1 \mathrm{gm}$, daily). Twenty-four hours afterward a second period ( $\mathrm{a}$ a, two days) was begun. The retention was now more than tenfold $(0.0265 \mathrm{gm}$. per kilogram). The administration of calcium chlorid was continued. Eight days after the second period a third period (II, ten days) showed about the same retention $(0.0212 \mathrm{gm}$. per kilogram). Calcium chlorid was now left out. In spite of this, the retention found in the last period was not altered; a fact, the probable explanation of which will appear from the discussion of the experiments. Craniotabes appeared in this infant shortly after the end of the experiments.

\section{DISCUSSION}

Three infants out of four studied had very low calcium retentions during the first months of life. This might possibly be ascribed to rachitis, as in all the infants craniotabes appeared in the second month. 'This assumption, however, is not in harmony with the fact that although the craniotabes in those cases which were followed further made progress in the subsequent months, the retentions increased to amounts as large as those found in normal infants. I wish further to call attention to the relatively normal retention of the infant A. L., period I, immediately before the craniotabes was clinically noted; the 
appearance of rachitic symptoms is generally believed to be preceded by low or negative calcium retentions. Lastly, the calcium metabolism in progressive rachitis cannot, as far as we know, be influenced by the administration of calcium, as was done in the case of the infant $O$.

There are, then, several discrepancies between these prematures and rachitic infants in respect to their calcium metabolism, its relations to clinical symptoms and therapeutic measures-discrepancies which justify the proposal of another explanation of their low retentions.

TABLE 3.-Total Intakes Compared with the Retentions Per Kilogram of Body Weight

\begin{tabular}{|c|c|c|c|c|c|c|c|}
\hline Case & Period & $\begin{array}{l}\text { 'lotal } \\
\text { Intake } \\
\text { in } \mathbf{~ M g . ~}\end{array}$ & $\begin{array}{c}\text { Retention } \\
\text { per Kg. of } \\
\text { Bodyweight }\end{array}$ & Case & Period & $\begin{array}{l}\text { Total } \\
\text { Intake } \\
\text { in Mg. }\end{array}$ & $\begin{array}{l}\text { retention } \\
\text { ser } \mathrm{Kg} \text {. of } \\
\text { odyweight }\end{array}$ \\
\hline $\begin{array}{l}\text { N. L. } \\
\text { S. P. } \\
\text { A. L. } \\
\text { O. } \\
\text { S. P. } \\
\text { N. L. } \\
\text { O. }\end{array}$ & $\begin{array}{l}\text { I } \\
\text { I } \\
\text { I } \\
\text { I } \\
\text { II } \\
\text { II } \\
\text { III }\end{array}$ & $\begin{array}{r}133.9 \\
136.2 \\
144.4 \\
163.7 \\
178.6 \\
187.6 \\
235.0\end{array}$ & $\begin{array}{r}9.0 \\
0.4 \\
16.7 \\
2.0 \\
5.7 \\
3.0 \\
23.1\end{array}$ & $\begin{array}{c}\text { A. L. } \\
\text { N. L. } \\
\text { O. } \\
\text { O. } \\
\text { N. L. } \\
\text { N. L. } \\
\text { A. L. }\end{array}$ & $\begin{array}{l}\text { II } \\
\text { III } \\
\text { Ia } \\
\text { II } \\
\text { IIIa } \\
\text { II } \\
\text { III }\end{array}$ & $\begin{array}{l}244.8 \\
269.5 \\
278.9 \\
282.3 \\
297.6 \\
309.2 \\
309.7\end{array}$ & $\begin{array}{l}12.8 \\
16.4 \\
26.5 \\
21.2 \\
16.5 \\
22.8 \\
22.9\end{array}$ \\
\hline
\end{tabular}

In Table 3 the rather remarkable fact is demonstrated that in those perious where the intakes exceed $200 \mathrm{mg}$, the retentions are sufficient (i. e., as large as in normal infants), while in the periods where the intakes are lower than this amount, there is sufficient retention only in one case. It is tempting to draw the conclusion that the intake must exceed a minimum of about $200 \mathrm{mg}$. if sufficient retent:ons are to be attained. The total calcium excreticn cannot, it seems, be pressed below a certain level. The calcium is excreted mainiy in the stools. The daily amount of feces excreted by prematures is very large, a fact which may be explained by the low fat absorption found in prematures by Rubner and Langstein. The daily values for the total solids ${ }^{3}$ in the stools are consequently high, higher than in normal infants, although the quantities of milk taken by the prematures are very small. The calcium percentages of the total solids were, in my experiments, found to be lower than in normal infants, not, however, sufficiently lowered to counterbalance the excess in total solids and the small intakes. To balance these factors, exceedingly low calcium percentages would have been necessary. It might be conceivable that for reasons unknown to us, such exceedingly low percentages cannot be attained under ordinary conditions.

Lindberg's experiment ${ }^{*}$ where an infant was alternately fed with ordinary breast milk and breast milk enriched with fat (breast milk

3. As fat analyses have not been made (because of lack of the necessary reagents) the following discussion is based on the values for total solids.

4. Loc. cit., Table 1. 
fat used), demonstrates that a high fat intake may in the breast fed infant lead to temporary losses of calcium. The increased fat intake was followed by an increased fat excretion, i. e., an increase of the daily amount of total solids in the stools; the dry weight of the stools increased 27 per cent. The calcium percentage, however, fell only 15 per cent., i. e., the increase in total solids was not balanced. Lindberg's experiment with high fat intake lasted only six days. During this time, the feces had the same characteristics as the feces of prematures: rich in fat and consequently in total solids; calcium percentage somewhat low, but not sufficiently lowered to bring about a good calcium retention. In the normal infant the cause was an excess of fat intake; if the experiment had been continued for a longer period, it is highly probable that some regulating mechanism would have been called into play and a normal calcium metabolism re-established. In the premature, the constantly low fat absorption suggests an insufficiency of the digestive mechanism. It is not inconceivable that this supposed insufficiency is also responsible for the low calcium retentions.

Holt and his co-workers " in their work on calcium and fat metabolism in bottle fed infants found no constant relation between calcium and fat excretion. The work of Lindberg demonstrates that in a breast fed infant with abnormally high fat intake such a relation may exist. Perhaps the experiments here reported may be interpreted thus: that in breast fed infants the same relation is found when the fat absorption is low.

In this discussion, an attempt has been made to find a plausible nonrachitic cause for the low calcium retention found in prematures. The argument would be strengthened if it could be demonstrated that these low retentions may be increased not only by a higher calcium intake but also by a lower fat intake. ${ }^{6}$ At present, however, the available facts are neither numerous nor complete enough to justify the drawing of definite conclusions.

I wish to thank Dr. A. Lichtenstein for taking the initiative in this work, and for his valuable advice and criticism.

5. Holt, Courtney and Fales: Calcium Metabolism of Infants and Young Children, and the Relation of Calcium to Fat Excretion in the Stools, Am. J. Dis. Child. 19:97 (Feb.) 1920.

6. In the discussion of this paper Dr. A. Ylppö announced that he had recently begun feeding prematures with centrifugated breast milk. The result of this experiment has not yet been published. 